Gender \& Behaviour; Volume 9 Number 2, December 2011 Copyright (C) 2011, Ife Center for Psychological Studies \& Services Ile-Ife, Nigeria

\title{
ARTICULATING CULTURES: SOCIO-CULTURAL EXPERIENCES OF BLACK FEMALE IMMIGRANT STUDENTS IN SOUTH AFRICAN SCHOOLS 1
}

\section{Saloshna Vandeyar* \& ThirusellvanVandeyar**}

*Department of Humanities Education, Faculty of Education, University of Pretoria, Groenkloof Campus,Leyds Street, Pretoria, 0002

Tel: 012 420-2003; Fax: 0124205637

Email: Saloshna.Vandeyar@up.ac.za

**Department of Science, Mathematics and Technology Education, Faculty of Education, University of Pretoria, Groenkloof Campus,Leyds Street, Pretoria, 0002

\begin{abstract}
Contests of space and place in South African 'schoolscapes' 2 are now not so much about 'race' as it is about nationalism and territoriality. While the politics of belonging unfolds and overtly manifests itself, a more covert, insidious and worrisome issue is that of the erosion of the social and cultural mores of Black ${ }^{3}$ immigrant students. Utilising social constructivism, case study approach and narrative inquiry, this study sets out to explore the socio-cultural experiences of Black female immigrant students in South African schools. It was found that the socio-cultural context of South African 'schoolscapes' represented a site of contamination and shame; was marred by conflict and contained elements that worked towards the erosion of cultural and social mores of Black female immigrant students.
\end{abstract}

Keywords: Immigrant students; socio-cultural; migration; xenophobia; schoolscape

\footnotetext{
1 This paper stems from a broader SANPAD-funded project on Immigrant student identities in South African schools.

${ }^{2}$ Schoolscape: The concept "schoolscape" has evolved from the concept of a 'scape' that was first proposed by Appadurai (1996) in his attempt to describe forces of globalisation and global cultural flows that are 'liquid'and irregular in nature. He introduced terms such as 'ethnoscape', 'technoscape', 'financescape', 'mediascape'and 'ideoscape', each of which emphasis a particular aspect of the world with the latter 'ideoscape' embodying the 'imagined worlds' produced through and intersection of all of the former scapes.

${ }^{3}$ Black- the term 'Black' derives from the apartheid racial classifications of the different peoples of South Africa, and is inclusive of Coloured, Indian and African. The use of these terms, although problematic, has continued through the post-apartheid era in the country. The term African refers to the indigenous black people of South African. In this paper, I use these terms grudgingly to help present the necessary context for my work.
} 


\section{Introduction}

The future of any country is vested in its youth. Youth are not only the future leaders and future constituents of the adult society of a country, they are also the cultural custodians entrusted with upholding cultural values and norms and continuing the cultural customs and traditions of a particular culture, associated with a particular geographic, social and political space and territory. The caregiver nurturing role of culture in terms of these customs and traditions in some cultures, particularly cultures in the Southern African Developing Community (SADC) have been vested in the hands of females. What happens in the case of transnational female youth who are uprooted from their home country and now find themselves in a new host country? How do they experience the disparate cultural streams each with its own unique cultural and moral codes of conduct, and dress? Do they experience a sense of cultural conflict or consensus? How do they identify and what implications do this hold in terms of their role as custodians of their culture? How do they balance the tightrope of maintaining their culture of origin while at the same time seeking a sense of belonging and acceptance in the host country? How do they remain true to their country of origin that has vested interests in its youth?

The advent of democracy in South Africa has witnessed an increasing number of Black immigrant students' entry into South African schools. The early years of democracy was marked by a trend that fixated on Black and White dynamics as an increasing number of Black indigenous students entered former white schools. Much research sought to capture this dynamic. Seventeen years of democracy has seen a notable shift in this debate in the form of a new dynamic unfolding at schools namely, that of Black immigrant students. Contests of space and place are now not so much about 'race' as it is about nationalism and territoriality. While the politics of belonging unfolds and manifests itself overtly, a more covert, silent and worrisome issue is that of the erosion of the social and cultural mores of Black immigrant students. Accordingly, this study asks, what are the socio-cultural experiences of Black female immigrant students in South African schools?

The argument is presented as follows. I sketch a brief background context to situate the identified intellectual puzzle. I then explore the literature in an attempt to determine findings from the major debates in this field of study. This is followed by a brief exposition of the theoretical framework that is utilised in this study. The findings are presented and subsequently analysed and 
discussed in an attempt to unpack the socio-cultural experiences of Black female immigrant students in South African schools.

\section{Background Context}

Socio-cultural experiences of Black immigrant students cannot be investigated in isolation of broader societal influences. In the case of South Africa, this phenomenon has to be understood against the backdrop of the broader context of migration and xenophobia in South Africa.

Migration to South Africa is an inevitable consequence of longstanding patterns of labour migration in mining and agriculture (Landau, Ramkathan-Keogh \& Singh, 2005; Crush 2008). Prior to 1994, the South African immigration policy was utilised as a tool of racial domination (Khan, 2007). Until 1991 the official definition of an immigrant was that he or she had to assimilate into the white population (Crush, 2008). Africans were not given the status of immigrants. They arrived in South Africa as contract migrants which gave rise to the South African migrant labour system (Crush, 2008). Over the past two decades however, there has been a notable increase in migration from the SADC region primarily due to the demise of apartheid in South Africa and the integration of South Africa into the global economy (Pendleton, 2008; Crush, 2008).Alongside this, South Africa has witnessed a rise in intolerance and animosity towards Black immigrants (Landau et. al; 2005; Harris, 2002; Reitzes, 2009) as evident from the 2008 xenophobic attacks in South Africa.

Five theses have been offered as an explanation of xenophobia in South Africa namely, the scapegoat thesis (Morris, 1998; Tshitereke, 1999)the relative deprivation thesis (Tshitereke, 1999; Pillay, 2008)the isolation theory (Morris, 1998) the biocultural theory (Harris, 2002) and the South African nationalism theory (Neocosmos, 2008).It is against this backdrop that this research study set out to explore the socio-cultural experiences of Black female immigrant students in South African schools.

The context of this study was limited to the Gauteng ${ }^{4}$ province of South Africa. The central cities of Gauteng have some of the largest numbers of black immigrants, who are diverse not only in terms of national origin, but by ethnic affiliation, cultural tradition, and generational status. The majority of black immigrant students in the Gauteng province of South Africa are

${ }^{4}$ Gauteng: One of nine provinces of South Africa that was established after the advent of democracy in South 
from Mozambique, Lesotho, Zimbabwe, Democratic Republic of Congo, Swaziland, Botswana, Angola and Malawi. Substantial numbers of immigrants also come from Zambia, Pakistan, Nigeria, Namibia, India, Kenya, Somalia, Uganda, Ruwanda, Ethopia, Sri Lanka, Tanzania and Mauritius (Department of Education, Ten day statistics, 2007).

Because black immigrant students are often grouped with African students on the basis of "race" there is very little known about their day to day experiences at schools. The data compiled in this regard is rarely segregated on the basis of any other social identity dimension. This homogeneous categorization of blacks ignores the important national, ethnic, linguistic, cultural, political, and even racial differences that exist within the population (Awokoya \& Clark, 2008). Several authors (Jackson \& Cochran, 2003; Traore \& Lukens, 2006; Awokaya \& Clark, 2008) claim that by presenting members of the African Diaspora as a monolithic group, the increasing racial and intra-racial strife that affects individual development and academic achievement, as well as school climate tends to be neglected.

\section{Exploring the terrain: Socio-cultural experiences of immigrant students 5}

Socio-cultural experiences encompass issues such as schooling experiences [academic and social experiences within and outside the classroom], language use, acculturation and identity formation (Chow, 2006; Grobler, Moloi, Bisschoff \& Mestry, 2006).Larson and Marsh (2005:339) define the term 'sociocultural' as

an awareness of students' backgrounds, personal histories, and that each student is "a product of the social, cultural, political, and historical forces that are present in any given time and place.

Much of the literature concurs that immigrant students experience adjustment adaptation problems when they enrol at schools in the host society (Traoré, 2004; Goyol, 2006; Ighodaro 1997). The transition of immigrant students into the host country is influenced by a number of factors such as discrimination, harassment, attrition, isolation, language barriers, social standing, cultural changes, social change, teaching styles, school environment, academic standing, sense of belongingness, and

\footnotetext{
${ }^{5}$ This literature review was first published in Vandeyar, S. (2010). Educational and Socio-cultural experiences of immigrant students in South Africanschools.Education Inquiry, Vol. 1 (4):347-365. Copyright of this literature review rests with this journal.
} 
identity (Qin, Way \& Mukerjee, 2008;Kunz, 2000).Strong work ethics, academic excellence and academic commitment often predispose immigrant students to prejudice from indigenous students (Qin et al., 2008) which, in turn, influence social relations between immigrant and host students. Bullying and harassment from the hegemonic cultural group at the host school concerning issues centred on territorial spaces have also been a cause for concern. Gibson and Carrasco (2009: 254) argue, although official school discourses appear to embrace cultural and linguistic diversity, foreignborn and native-born children of immigrants often end up feeling silenced and alienated.

A significant factor is language, which serves as a gatekeeper for acceptance in the host society. It also serves the purpose of forming the foundation for interaction and acculturation among immigrants and indigenous students in the host society (Yeh, Okubo, Ma, Shea, Ou \& Pituc, 2008). Osborn and Osborn (2005: 4) argue that

language is a basic human right and the opportunity to learn from other 'cultures' is fundamental to an education in a democratic society.

When immigrants are deprived and destitute of the basic tenets of language in a community, there is possibility of exclusion. In the host society, the issue of language is not always comprehensible by minority groups because "language is not just a cultural issue but a political one" (Wang \& Phillion 2007:95); in essence, the inability of minority groups to communicate well in mainstream culture may lead to their exclusion at school and in the host society (Sayed, 2002, Sayed, Soudien \& Carrim, 2003; Osborn \& Osborn, 2005). Even where literacy levels are good, and years of schooling are commensurate with chronological age, many immigrant and refugee students find the "mainstream curriculum and its language demands very difficult" (Brown, 2006: 150).

The languages spoken by students, which are eventually spoken at school, are resources because didactic cultures are based on the previous understanding and training learners have had over the years in their home language (Nieto, 2002).Nieto (2002: 83) argues that "educators by and large accept as one of their primary responsibilities the language assimilation of their students" because, without proper language proficiency in academic matters, academic achievement becomes far-fetched (Chow, 2000, 2001; Rumberger \& Larson, 1998; Goddard \& Foster, 2002).Chow (2006: 2) argues, 
proficiency in English is a major consideration in the necessity, rapidity, and ease with which immigrants adapt to a milieu dominated by English. It is required for communication and for the acquisition of information about the new society.

Issues pertaining to language are very sensitive to the acculturation process and the "belongingness" of immigrants at school (Wang \& Phillion, 2007; Soto, 1997).Taylor and Doherty (2005) argue that immigrants who are new to their host country, especially those who cannot interact with dominant students because of a language barrier, are also prone to experiencing difficulties in participating in sporting and recreational activities. When Black immigrant students enter schools they are not seen as any different to Black African students, but are heard differently because of their accent. Their accent may be viewed as a major identifier that separates them from the black Africans who are native (Aikhionbare, 2007; Fischer, 2004).

Another point of consideration when evaluating immigrant students' academic performance, borders on the congruence existing between the teaching styles used by their teachers back home and in their host society. It has been found that the use of good teaching skills and a good rapport between the teacher and students enabled immigrant students who were English language learners to have a vivid understanding and keen interest in learning at school (Salinas, Franquiz, \& Reidel, 2008).

The degree of belonging to the school centres on how and who immigrants associate and identify with in a bid to shape their identities, which represents the road to acculturating to their new environment. Dika and Singh (2002) imply that, in order to gain an understanding of the schooling experience of immigrant students, pertinent issues like their level of affiliation, commitment and identity should be considered. A common occurrence among immigrants is the persistent feeling of not being sustained, a feeling of not being important, and caginess (Gibson, Gándara \& Koyama, 2004; Noguera \& Wing, 2006). When immigrants identify with the school environment they are able to "quickly discover that schooling is essential to success" in their host country so as to be able to ascend the steps of social class mobility (Delgado-Gaitan 1994: 137).

Acculturation is one of the dimensions that can be used to determine the extent of belonging among immigrant groups of children to their mainstream culture (Berry, 1995; LaFromboise, 
Coleman \& Gerton, 1993; Yeh\&Inose, 2003; Yeh, 2003; Mouw \& Xie, 1999). Acculturation denotes the way people bargain in the midst of cultural diversities with the assumption that there are hierarchies in terms of the affiliation to one or more cultures than others. This is usually recognised when such individuals describe their identities to show their degree of affiliation to cultural preferences (Berry, 1995; LaFromboise, et. al, 1993).The process of acculturation borders on knowing and taking on the way of life and customs of the "adopted society". The level of acculturation of a student is often an indicator of a student's integration into a school environment. Students with low levels of acculturation to the dominant culture often experience the stress of integrating the environment of school with their own cultural background of home (Gonzalez \& Padilla, 1997). Furthermore, some studies have suggested that the ethnicity of a student's teacher can negatively affect a student's academic performance (Banks \& Banks, 2001). Teachers who may lack a sense of multiculturalism in the classroom may hinder some students' level of adjustment in school.

Identity formation is linked to the acculturation of immigrants to their host society. In the formation of identity, hybrids emerge depending on the experiences of immigrants in their host society (Vandeyar, 2008; Asanova, 2005).It has also been demonstrated that identity formation depends on the degree of affiliation of immigrants to home cultures and the transnational space enterprise existing between the two cultures. Two pertinent concepts in the formation of identity are that of the "social mirror" (Winicott, 1971) and "psychosocial passing"(Berry, 1997; Nesdale, Rooney \& Smith 1997; Suarez-Orozco \& Suarez-Orozco, 2001; SuarezOrozco, 2004; Murrell, 1999; Wu, 2002). Winicott (1971) suggests that a child's sense of self is profoundly shaped by the reflections mirrored back to him by significant others. "Psychosocial passing" refers to people who seek to render invisible the visible differences between themselves and a desired or chosen reference group.

The abovementioned factors of schooling experiences, language use, acculturation, sense of belongingness and identity formation directly influence the socio-cultural experiences of immigrant students and serve to either affirm or negate the very essence of their beings.

\section{Theoretical Mooring: Socio-cultural theory}

The theoretical underpinnings of socio-cultural theory are drawn from Vygotskian theories (1978) of learning which emphasize that learning occurs within a social world. This theory takes as its premise that the individual learner must be studied within a 
particular social and cultural context (Blanton, 1998; Flem, Moen, \& Gudmundsdottir, 2000; MacGillivray \& Rueda, 2001; Patsula, 1999, Tharp \& Gallimore, 1988) as the manner in which an individual makes meaning of the world is mediated through society and culture (Bruner, 1997; Cole,1996; Kozulin, 2003; Rogoff, 2003).Based on this premise proponents of this theory argue that individuals cannot be considered in isolation from their social and historical context and therefore it is necessary to look at the society and the developments occurring at a given time(John-Steiner \& Mahn, 1996:191). According to sociocultural theorists, meaning emerges from the interplay between actors within social contexts and mediators such as tools, language, activity structures, signs, and symbol systems that exist in that context(Blanton, 1998; Riddle \& Dabbagh, 1999). Individuals both shape and are shaped by these mediators. Thus, culture, environment and history play a crucial in this interplay of learning.

Socio-cultural theory rests on three prongs. First, thought and language are inherently connected and central to learning and development. According to Vygotsky (1978) speaking is a cognitive tool for internalising our social interactions and a mediating tool for communicating with others. Second, the influence of the social, cultural and political environment of learners influences the social interactions that take place with others. And third, the zone of proximal development (Wink \& Putney, 2002). Vygotsky's notion of the zone of proximal development refers to the level of development attained when learners engage in social behaviour (Blanton, 1998; Kearsley, 2005; Riddle \& Dabbagh, 1999; Scherba de Valenzula, 2002). Zone of proximal development is defined as the distance between the actual development level and the level of potential development (Vykotsky, 1978) and links the known with the unknown.

Two concepts emanating from classroom research conducted by socio-cultural theorists that are very apt for this study are that of 'borderlands' coined by Anzadua (1987:i) to describe the places where 'two or more cultures edge each other" and "hybrid spaces'(Gutierrez, Rymes\& Larson, 1995; Barton, Tan \& Rivet, 2008). 'Hybrid spaces' are spaces within schools that mix multiple cultural communities' norms and practices. A combination of these ideas, namely 'borderland' and 'hybrid spaces' is utilised in this study to understand the experiences of female immigrant students within the learning environment of South African schools. Socio-cultural theory thus provides an appropriate framework for this study as it "emphasizes the importance of context, the nature of human interactions and the 
reciprocal relationships formed between tools and their users" (Schuck \& Kearney, 2007:73).

\section{Research Strategy}

The meta-theoretical paradigm utilised in this study was that of social constructivism. The methodological paradigm employed a qualitative case study approach and narrative inquiry. Data collection was a mix of semi-structured interviews, observations, document analysis, field notes and researcher journal. Content analysis and ground theory approaches were utilised to analyse the data.

Three secondary schools located in the Gauteng province of South Africa provided the research sites for this study; a former white Model C school 6 , a former Indian school ${ }^{7}$ and an inner city school $^{8}$ that had a majority of black African learners. Criteria used in the selection of students were based on racial background and gender. Approximately fifteen [black] immigrant students (Lesotho, Kenya, Nigeria, Malawi, Congo, Zimbabwe, Mozambique, India, Pakistan, Sri Lanka) across Grades 8 to 10 were selected at each school. The selection of immigrant students depended on the mixture that was found at each of the identified schools. An attempt was be made to include both Anglophone and Francophone immigrant students in this study. A total of 45 students were interviewed. These interviews were conducted in 2009 over a period of six months. Questions comprised of five to six broad categories and were open-ended. The duration of interviews ranged between 90 and 120 minutes. All interviews were recorded and transcribed. Semi-structured interviews were conducted with the principal, the School Management Team, the School Governing Body, selected teachers of these Grades (8 -10) and parents of immigrant children at each of the three research sites.

Observations were conducted to coincide with the interview period. Researchers observed immigrant students over a period of six weeks at each school with a focus on their experiences of school life and how it plays out on the classroom floor and school grounds. Observations of classroom practice, activities and associations during the break sessions, assemblies and other

\footnotetext{
${ }^{6}$ Model C school: a government attempt to cut state costs by shifting some of the financing and control of White schools to parents

7 Indian school: A school that was designed and built to cater exclusively to the 'Indian' population.

${ }^{8}$ Inner city school: This is a school that has mushroomed out of the need to cater for children living within the inner

city
} 
activities of the school including after school activities were captured.

\section{Findings: The becoming self in conflict}

The becoming self namely, Black female immigrant youth, struggled to construct and negotiate their identity and to evolve into confident and independent individuals as the socio-cultural contexts within which they found themselves represented a site of contamination and shame. This site was marred by conflict; challenged their social, cultural and moral values; ignored their social, cultural and linguistic capital by adopting an assimilatory approach and contained elements that worked towards the erosion of their cultural and social mores. Conflict took form and found expression in differing value systems related to immoral behaviour(codes of dressing and conduct, respect, discipline etc.), identity formation, language and a sense of belonging.

Black female immigrant students found that their ingrained value systems were being challenged within the South African 'schoolscape'. Subsequently a conflict in values emerged as female immigrant youth tried to hold onto the values system that they had inherited from their respective countries of origin while simultaneously attempting to find a niche and acceptance in the host country. Conflict in values centred on issues of disrespect, ill-discipline, codes of conduct, fighting and inappropriate dress codes of indigenous students. They found that black indigenous students indulged in activities that they could not condone. A further concern for many black female immigrant youth was the fact that black indigenous students seemed to readily forsake their own cultures in an attempt to embrace and assimilate into the western culture. As a result, many black indigenous students seemed to be 'culture deficient'.

One way of articulating culture is through dress codes. Dress is a more visible, tangible and outward expression of one's culture. Many cultures pride themselves on their sense of dress as it is a symbol and signifier of a proud heritage and lineage. Most cultures attach a particular dress code to males and females with restrictions placed on what is regarded as decent or indecent in terms of exposure of the body and so forth. Cultures from the SADC region are no different in this regard, as evident from the following sentiments expressed by carriers of such cultures, In my culture we are not allowed to wear trousers or to have a boyfriend when you're still at school. You can have a boyfriend when you're 
matured enough like 20 or 21 . But here, it's different because they [South Africans] wear clothes that really make them look like 'loose', like they have no morals and do totally different things, like drinking, smoking and drugs (Venah, Angola).

If my clothes or dressing is not appropriate, my parents would tell me that it's not appropriate. In Zimbabwe your dressing depends on what you're doing and where you are. We have to wear like appropriate clothing. We don't wear clothes that some people wear like trousers when you go to visit your relatives or your grandparents. We are not allowed to dress that way because it wouldn't look like you're respecting them. Also, we can't wear open clothes that show your body, but here some of them because sometimes you look at someone and you're like this person isn't wearing something nice, appropriate for walking around (Alice, Zimbabwe).

I am different from other girls in South Africa maybe by what I wear. In our culture, we don't wear like trousers or whatever. I always wear skirts and traditional clothes (Angela, Ghana).

Another outward articulation of culture is the manner in which you conduct yourself or your code of conduct. This takes form in such qualities as respect, discipline, language usage, and general moral behaviour. Many black female immigrant students were extremely piqued by the code of conduct of black indigenous students and vehemently expressed their sense of disgust,

There is more discipline back home [country of origin], it's more difficult to misbehave. Here sometimes the learners will talk back to the teacher...Eish! They don't respect their teachers (Ogina, Cameroon).

There are certain things that make me feel pity for teachers. They really suffer. Students are very rude. They don't listen. They laugh and mock at teachers. The black South Africans insult teachers in class...it's the background, 
charity begins at home. You can see that a particular student is disrespectful to his parents because he speaks to teachers the way he wants to. This pains me a lot (Annie, Zambia).

The classes are quieter in Zimbabwe. Here most of the children make a noise; they play, gamble, swear and get into fights all the time. They have no respect for their teachers. They are illmannered and have no discipline at all (Brenda, Nigeria).

It would seem that the ills of society that are normally associated with the adult world had descended on schools in the form of dating, smoking, drinking, gambling, drugs and fights. Many black female immigrant students bemoaned the fact that the 'schoolscape' had become infected with immoral behaviour that was not conducive to an educative environment. They claimed that teachers spent much time addressing issues of ill-discipline and immoral behaviour to the detriment of quality teaching time.

Dating at a young age seemed to be the 'cool' thing for local black students, despite the serious threat of HIV/Aids. This lackadaisical attitude has also led to an increase in teenage pregnancies (Panday, et. al, 2009) and consequently to an increase in abortions.

In our culture, a boyfriend is someone you can have at a certain age and he must be someone that the relationship can lead to a marriage. The bad side of South African culture is the dressing, the disrespect, drinking, smoking, drugs and this whole issue of boyfriends (Vanessa, Congo).

Like me, I don't date, not at all...so a friend of mine can just tell me. Oh no, dating is fun and you must go. But I know it is wrong at this age (Annika, Angola).

While Andrew 'passed' as one of the local blacks because of his phenotypic features, he was adamant that he is different from them in terms of his behaviour

At home, we are not allowed to smoke. Here they smoke. At home, no gambling. I feel like different because of the way they [South Africans] behave (Nyirenda, Ghana). 
The use of obscene or vulgar language was another variable that irked many Black female immigrant students. They felt that it was unbecoming and undignified especially for females to talk in such a manner. Yet, to many Black indigenous students it was more the norm than the exception. Angela, a Malawian narrates an incident of verbal abuse. Things sounded very strange to Angela on her first day at school. Angela termed this a 'vacuum' or 'space'.

It's what they do. I didn't know that until when I came here... 'F you'. That's strange language. I heard many children saying this on my very first day at this school. I asked a friend that I had just met, what does it mean?

Interviewer: What impact did it have on you once you understood what it meant?

"It's not language I would like to use on anybody". It's not lady-like. It's says a lot about the cultures in South Africa.

Fighting seemed to be commonplace among local black students. Much of their energies were invested in petty issues and in provoking and testing the mettle of each other, rather than concentrating on their studies.

Immigrant children are quiet. They don't cause any trouble. They are so different, very strict sort of upbringing, so they just tow the line. The local black students...oh, that's another cup of tea...they are constantly in fights. They should learn how to behave from immigrant students (Mrs. Lopes, principal Opulence High).

An inner and internalised articulation of culture is that of identity. How one identifies gives form to the outer expressions of culture. For many black female immigrants, racial and ethnic identities are fluid and complex, thus many of them did not strictly identify with the rigid and dichotomous black/white constructs through which racial and ethnic identities are based in South Africa. Evidence of dominating ethnic identities, hyphenated identities, and imposed identities came to the fore.

Vena sees herself first and foremost as a person and as an African from Zimbabwe. She dislikes the fact that she is expected to classify herself according to a particular category in South 
Africa. However, South African societal norms and practices force her to orientate her thinking so that the abnormal takes on a feigned sense of normalcy within the context, in which she finds herself,

I feel that as a person, I'm supposed to hang out with the black people. It's just, I don't know how it happens but it's very weird. I feel like I have to be with the black people as a 'black' person. I've heard people saying that as well because like you just see all the black people are friends with black people. White people are friends with white people so I think if I have to go to white people and tell them guys, I want to spend break with you it will obviously be weird. Yeah, maybe it's normal in South Africa but, I don't like that, I feel that if I want to hang out with the white people then I should do that, I should go to them and they shouldn't feel weird about it like none of us should feel weird, we should really feel like it must be like a normal thing. I don't really know if it's expected but it's just one of those natural things, like an unwritten rule of the school. I get to school and I think I'm probably going to end up with the black people kind of thing.

Immigrants who arrive to South Africa and find themselves classified in ethnic terms and labelled as Black or Africans, often feel that other kinds of descriptions may be more suitable to identify them, as evident from this vignette.

Interviewer: Would you class yourself according to

colour?

Immigrant: Yes.

Interviewer: Who would you say you are?

Immigrant: I'm black; I'm African.

Interviewer: Why do you say you are an African?

Immigrant: Because I originate from Africa.

Interviewer: And why do you call yourself black?

Immigrant: Because that's how we're classified by the South African government.

Interviewer: Are you happy with that?

Immigrant: Not really, because I've heard so many people complain about being called black because our skin colour is naturally black.

Interviewer: So you won't classify yourself as black in Zambia? 
Immigrant: Me, no, no, no definitely not! I was not identified as 'black' in

Zambia, but here I am told that I am 'black' because I look more like the local black Africans than like the Indians and whites.

Interviewer: In Zambia, how would you classify yourself?

Immigrant: As African.

Interviewer: Just African?

Immigrant: Yes. It is only when I came to South Africa that I realized that

I've got another label, now I am a black African.

Interviewer: How does this make you feel?

Immigrant: I feel bad because I am not 'black' I am 'African'... because I come from Africa. "I am not happy about being called black. I prefer being called African'. Also, my culture is totally different from theirs [black South Africans] and in my culture we are taught to respect and behave well. We also dress differently. There are so many differences with them so how can people see me like one of them? I am just an African student in South Africa from Zambia... all these other labels; black and all that doesn't get into my identity.

Black female immigrant students also tried to negotiate and balance and contours of the hyphen as they tried to navigate their way through the socio-cultural contexts of the host country and to seek a sense of belonging,

I wouldn't say I'm a foreigner, no. I am a Rwandan-South African, yes. I'm... who I am is two different cultures that play a huge, huge, impact on me and sadly I'm going say it's more South African than Rwandan people that have made me who I am. But because culture means a lot to me, I have to say I am Rwandan-South African (Janet, Rwanda).

Furthermore, many Black female immigrant students found that within the socio-cultural context of the host country, they had 
been plugged into an identity category that they detested namely, 'makwerekwere',

They tell me to go back to where I came from ...I am a foreigner, a makwerekwere or something like that. I hate that word (Helen, Mozambique).

I'm a Congolese girl from the DRC. They say I am a foreigner; a makwerewere and they push me and say 'Go back to your country'. I don't see myself as a foreigner. I am an African from Africa (Jeanette, DRC).

They call me a foreigner because of my accent. They like make jokes about the way I talk (Brenda, Nigeria).

In an attempt to avoid immigrant stress, some Black female immigrant students chose to hide their identities and attempted to 'pass' for one of the indigenous students,

Well they didn't really see me as an immigrant I was just like one of them. So I just let them go on believing that I am one of them. I don't let them know that I am really an immigrant (Belece, Malawi).

I don't say I am from Zimbabwe. I try to hide it, just to fit in so that they don't treat me differently. It would like change the way they treat me like before they knew I was Zimbabwean. If you are Zimbabwean, sometimes you won't have friends or some, they just ignore you (Teresa, Zimbabwe).

Discrimination against Black female immigrant students also took the form of 'shades of blackness',

They use my surname Dakar to mock at me and they say I am dark. I am a makwerekwere and I must go back to Zambia (Effie).

They say you are black, like you are black more than other learners; you must be Congolese or maybe you from Somalia? (Jeannette, Congo).

The rural/urban binary also surfaced in this study (Neocosmos, 2006:6).Apartheid ruralised and devalued black lives while urbanising and valuing whiteness. This binary has shifted to the 
African/South African polarities whereby African is seen as rural and backward and South African as urban, modern and a world class African country,

Before the exam we were in the hall and my friend and I were playing the piano in the hall, this South African guy comes in and he says 'is there no piano in your country? I thought like, what do you think we are in our country? (Aline, Rwandan).

No, but some people would just be surprised 'because when I swim some people will be surprised. Oh, you can swim and which school did attend? Are there swimming pools in Zimbabwe... and stuff? I have to tell them the truth, that there are swimming pools in Zimbabwe and that they must not always like criticize that story which is happening to what I am (Alice, Zimbabwean).

A more vociferous form of articulating cultures is that of language. Within the socio-cultural South African's schoolscape' language was used as a means of exclusion on two levels: academic and social. Academic exclusion took the form of the teacher's teaching strategy,

I feel like an outsider when everyone is talking in another language that I don't understand. Like you have this teacher, she reads in English... the essays but then, she explains in Sotho and I cannot understand and we always like I mean...can you speak in English? She would speak in English for a while and then she'll go back to Sotho (Melody, Burundi).

The South African learners and teachers talk Sotho most of the time. They like start speaking English and then, they go into Sotho, like especially if one of the students asks a question, then they reply in Sotho and then the rest of the lesson continues in Sotho (Crystal, Zambia).

Social exclusion played out in terms of indigenous student's language usage during break. Indigenous black students used code-switching during breaks to entrench social exclusion. Many indigenous black students utilised the power of the indigenous languages to exclude immigrant students from their social networks. During breaks one could witness pockets of ethnic 
groups intensely engaged in casual conversations through the use of indigenous languages.

They don't speak English when we in a group. I have to tell them English, English please and then they get all nasty and say you don't belong here (Annie, Zambia).

The above practices related to language usage reinforced a sense of non-belongingness and exclusion in Black female immigrant students.

\section{Analysis and discussion of findings}

What do we learn about the experiences of Black female immigrant students within the socio-cultural context of the South African 'schoolscape'? Socio-cultural experiences can serve to either affirm or negate the very essence of Black female immigrant students. Some of the findings from this research study resonate with findings in the literature. First, this study also found that immigrant students experienced adjustment adaptation problems in schools. Almost all Black female immigrant students within the South African 'schoolscape' experienced discrimination, harassment, attrition, isolation, language barriers, cultural and social changes, conflicting values, tension regarding territorial spaces and a sense of non-belongingness. Second, similar to the findings in the literature, this study also found that the teaching styles and the ethnicity of the teacher negatively affected student's academic spaces of learning. Third, the formation of immigrant students' identities depended on the degree of affiliation of immigrants to the home and host culture and the transnational space existing between the two cultures. Hence, many immigrant students identified in terms of dominating ethnic identities and hyphenated identities. Fourth, identities born of the prevailing South African mind-sets were imposed on immigrant students namely, the categories of 'Black' and 'makwerekwere'.

Where the findings differ with that of the literature is in terms of language, shades of blackness and acculturation. This study also found that language served as a gatekeeper for acceptance in the host country. Issues pertaining to language were very sensitive to the acculturation process and the "belongingness" of immigrants at school (Wang \& Phillion, 2007; Soto, 1997). The difference however was that whereas much of the literature cites proficiency in English as a significant factor to adapt to the dominant culture of the host country, this study found that many Black female immigrant students attempted to become proficient in an indigenous language in a bid for academic and social inclusivity. A further factor compounding the issue of language was that of 
accent. Utilising language as a means to articulate their cultures, many female immigrant students discovered that their accent became a conspicuously articulate and visible marker for nonbelongingness and discrimination.

Coupled to accent was the issue of shades of blackness which was another instantaneous and visible marker for discriminatory practices. The South African oppressed turned oppressor. Black indigenous students discriminated against Black immigrant students on the basis of their shade of blackness. They could with ease identify which country an immigrant student came from in terms of their shade of blackness. Dynamics within the 'schoolscape' had shifted from the black/white binary to a black/black contest.

Some Black female immigrant students tried to counter this contestation by utilising the strategy of psychosocial passing. Others chose a process of acculturation which borders on knowing and taking on the way of life and customs of the "adopted society". However, many Black female immigrant students only attempted to do this in terms of learning the local dialect as a means to understand and to try to fit into the sociocultural context of the school. Despite the fact of the rural/urban binary which sees Africa as rural and backward and South Africa as urban and modern, most Black female immigrant students were hesitant to take on the life and customs and associated aspects of modernity of the host country. They experienced the host country as a site of contamination and shame. The level of acculturation of a student is often an indicator of a student's integration into a school environment. Black female immigrant students thus did not fully integrate into the South African 'schoolscape'.

What implications does the South African socio-cultural 'schoolscape' hold for the education of Black female immigrant students? Education viewed from a socio-cultural perspective seeks to understand the social and cultural worlds within which individuals have grown and developed, how individuals interpret who they are in relation to others, and how they have learned to process, interpret, and encode their world (Perez, 1998).In this study, it became evident that both the concepts of 'borderlands' (Anzadua, 1987:i) and 'hybrid spaces'(Gutierrez, Rymes \& Larson, 1995; Barton, Tan \& Rivet, 2008) played out within the South African 'schoolscape'. Schools had a mix of multiple cultural communities' norms and practices where two or more cultures edged each other. 
The first prong on which socio-cultural theory rests namely, thought and language are inherently connected and central to learning and development was clearly evident in this study. Speaking was utilised as a cognitive tool by black female immigrant students for internalising their social interactions and as a mediating tool for communicating with others. Attempts were also made to learn the local dialect, not only to find a sense of belonging but more importantly to enhance understanding and learning, since both teachers and students code-switched during lessons.

The second prong of socio-cultural theory looks at how the social, cultural and political environment of learners influences the social interactions that take place with others. This study found that learning and knowledge were inextricably intertwined with the context within which they occurred. The context also moved beyond physical location and was inclusive of individual, cultural, social, institutional and historical locations (Lave \& Wenger, 1991).Social interactions were inhibited due to a lack of proficiency in the local dialect. Many Black female immigrant students did not want to associate with the cultural environment that was representative of Black indigenous students. Furthermore, the political environment excluded Black immigrant students and labelled them as 'makwerekwere'.

The third prong of socio-cultural theory is Vygotsky's notion of the zone of proximal development (ZPD). This refers to the level of development attained when learners engage in social behaviour (Blanton, 1998; Kearsley, 2005; Riddle \& Dabbagh, 1999; Scherba de Valenzula, 2002) and is defined as the distance between the actual development level and the level of potential development (Vykotsky, 1978). ZPD links the known with the unknown. In this study it was found that Black female immigrant students' level of social behaviour was informed by sound moral principles as compared to that of the Black indigenous students. The context provided an opportunity for Black female immigrant students to learn from the negative aspects portrayed by Black indigenous students and this was used as a springboard for their potential level of development. In terms of linking the known to the unknown, many Black female immigrant students were disadvantaged as the socio-cultural context of the 'schoolscape' did not affirm or draw on their cultural or social capital or attempt to use it as an asset. Hence, scaffolding did not take place between immigrant students existing schemata of knowledge and new knowledge. Instead an assimilatory approach was the favoured option. Many Black female immigrant students 
did not want to nor did they aspire to assimilate into the Black indigenous cultures which they perceived in a negative light.

\section{Conclusion}

South Africa represents a land of opportunity to many Black immigrants, thus the increasing flow of Black immigrants into the country. It is viewed especially by the SADC region as a world class African country that presents many economic, social, cultural, educational and political opportunities. This study has found that while many such opportunities exist it comes at a moral price.

Black immigrant students in secondary schools are steeped within the socio-cultural settings of the South African 'schoolscape' for a period of no less than five years. It was found that such settings not only challenge but also put in place a process of erosion of the social and cultural mores of Black female immigrant students.

These students are at an impressionable age confined to the socio-cultural 'schoolscape' where articulating cultures and the work of 'borderland' are at play. Cultures 'edge' each other in a bid to establish territorial spaces and power. These students are also at an age where they are constructing, negotiating and representing their identities en-route to adulthood. Although they may now view the host country as a site of contamination and shame, the desire to fit in; seek acceptance and aspire to be 'modern' may become too great to resist. There is also the imminent danger that some Black immigrant students may perceive South Africa to be representative of the norm of the western world and they may begin to question their ingrained value systems. How long before Black female immigrant students buckle under socio-cultural pressure, if not already? How long before countries of origin take note of the forces eroding away at its social and cultural heritage? Is the quest for "South Africanness" and South African citizenship worth the social, cultural and moral risk? Is it fair to silence articulating cultures of Black immigrant students? 


\section{References}

Aikhionbare, C. E. (2007). Transition of African Adolescent Immigrants into Urban or Suburban Schools. Unpublished doctoral dissertation. University of Cincinnati.

Anzaldua, G. (1987). Borderlands/La Frontera: The new Mestiza. San Francisco: Spinsters / Aunt Lute.

Appadurai, A. (1996). Modernity at Large: Cultural dimensions of globalisation. USA: University of Minnesota Press.

Asanova, J. (2005). Educating Ethnic Minority Children: The Case of Canada. In: The Education of Diverse Student Populations. Vol.2 Springer Netherlands pp 65-77.

Awokoya, J. T. \&Clark, C.(2008). Demystifying cultural theories and practices: Locating Black immigrant experiences in teacher education research. (Higher Education) (Report). Multicultural Education, 16 (2), 49-58.

Banks, J. A. \& Banks, C. A. (2001). Multicultural Education: Issues and perspectives. New York: John Wiley \& Sons, Inc.

Barton, A.C., Tan, E.\& Rivet, A. (2008). Creating hybrid spaces for engaging school science among urban middle school girls. American Education Research Journal, 45 (91), 68103.

Berry, J. W.(1995). 'Psychology of acculturation' In: N. R. Goldberger\& J. B. Veroff, (ed). The culture and psychology reader. New York: New York University Press, 457- 488.

Blanton, M. L. (1998). Prospective teachers emerging pedagogical content knowledge during the professional semester. Unpublished Doctoral Dissertation. North Carolina State University.

[Online] http://www.ncsu.edu/crmse/research_papers/blanton.di ss.doc [17 October, 2008].

Brown, R. (2006). The TDSB grade 9 cohort study: A five-year analysis 2002-2005. Research Report. Toronto District School Board (Toronto, ON: Toronto District School Board)

Bruner, Jerome, S.(1997). Celebrating divergence: Piaget and Vygotsky.Human Development, 40(2), 63-73.

Chow, M. (2006). Vietnamese-Canadian University Students in Regina: Socio-cultural and Educational Adaptation. Canadian Ethnic Studies, 38(2), 2.

Chow, H. P. H. (2001). English-language use among Chinese adolescent immigrants.

The Alberta Journal of Educational Research, 47(2), 191-195.

Chow, H.P.H. (2000). The determinants of academic performance: Hong Kong immigrant students in Canadian schools', Canadian Ethnic Studies, 32(3), 105-110.

Cole, M. (1996). Cultural Psychology. Cambridge, MA: Harvard University Press. 
Crush, J. (2008). South Africa: policy in the Face of Xenophobia. [Online] Southern African Migration Project (SAMP). Migration Information Source. Available from:

http://www.migrationinformation.rg/USfocus/display.cfm ?ID=689. [Accessed 19 July 2011].

Delgado-Gaitan, C. (1994). Russian refugee families: Accommodating aspirations through education. Anthropology and Education Quarterly, 25(2), 137-155.

Department of Education. (2007). Ten day statistics.

Dika, S. \& Singh, K. (2002). Applications of social capital in educational literature: a critical synthesis. Review of Educational Research,77(1), 31-60.

Fischer, M. (2004). Emergent forms of life and the anthropological voice (Durham, Duke University Press).

Flem, A., Moen, T.\& Gudmundsdottir, S. (2000). Towards inclusive schools: a study of how a teacher facilitated differentiated instruction. Paper presented at the ECER Conference, Edinburgh.

Gibson, A. \& Carrasco, S. (2009). The Education of Immigrant Youth: Some Lessons from the U.S. and Spain. Theory into Practice. 48 (4), 249-257.

Gibson, M., Gándara, P. \& Koyama, J.(2004). School Connections: U.S. Mexican Youth, Peers, and School Achievement. New York: Teachers College Press.

Goddard, J. T. \& Foster, R. (2002). Where cultures collide: Educational issues in northern Alberta. Canadian Journal of Education, 27 (1), 21-40.

Gonzalez, R. \& Padilla, A. M. (1997). The academic resilience of Mexican American high school students. Hispanic Journal of Behavioral Sciences, 19 (3), 301-317.

Goyol, A. B. (2006). Adjustment problems of African students at public universities in America. Lanhan, MD: University Press of America, Inc.

Grobler, B. R., Moloi, K. C., Bisschoff, T. C. \& Mestry, R. J. (2006). Creating a School Environment for the Effective Management of Cultural Diversity. Educational Management, Administration \& Leadership, 34 (4), 449472.

Gutierrez, K.,Rymes, B. \& Larson, J. (1995). Script, counterscript, and underlife in the classroom: James Brown versus Browm v. Board of Education. Harvard Educational Review, 65 (3), 445-471.

Harris, B.(2002). Xenophobia: a new pathology for a new South Africa? In. D. Hook \& G. Eagel (Eds) Psychopathology and Social Prejudice. Cape Town: University of Cape own Press, 169-184. Available from:http://www.csvr.org.za/wits/papers/paphari.html 
[Accessed 22 July].

Ighodaro, M. (1997). Experience of Somali Students in MetroToronto School System. Unpublished master's thesis, York University, Toronto, Canada

Jackson, J. \& Cochran, M.(2003). Black versus black: The relationships among African, African American, and African Caribbean persons. Journal of Black Studies, 33, 576-604.

John-Steiner, V. \& Mahn, H. (1996). Socio-cultural approaches to learning and development: A Vygotskian framework. Educational Psychologist, 31(314), 191-206.

Kearsley, G. (2005). Social Development Theory. Theory into Practice Database. [Online] http://tip.psychology.org/vygotsky.html [20 August, 2010].

Khan, F.(2007). Patterns and policies of migration in South Africa: Changing patterns and the need for a comprehensive approach. Paper drafted for discussion on. Patterns on policies of migration. Loreto, Italy. October 2007.

Kozulin, A. (2003). Psychological tools and mediated learning. In: A. Kszllin \& B.Gindis \& V. S. Ageyev \& S. M. Miller (Eds.), Vygotsky's educational theory in cultural context (pp. 1538). New York: Cambridge University Press.

Kunz, J. (2000). Immigrant youth in Canada. (Ottawa, Canadian Council on Social Development).

LaFromboise. T., Coleman. H. \&Gerton,J. (1993). Psychological impact of biculturalism: Evidence and theory. Psychological Bulletin.

Landau, L.B., Ramkathan-Keogh, K. \&Singh, G. (2005). Xenophobia in South Africa and Problems Related to It. Forced Migration Working Paper Series 13. Johannesburg: Wits University Press.

Larson, J., \& Marsh, J. (2005). Making literacy real: Theories and practices for learning and teaching. Sage: London.

Lave, J \& Wenger, E. (1991). Situated learning: Legitimate peripheral participation. Cambridge, MA: Cambridge University Press.

MacGillivray, L. \& Rueda, R. (2001). Listening to inner city teachers of English language learners: Differentiating literacy instruction. Education Research and Development Centres Program. [Online] http://www.ciera.org/library/archive/200105/0105McRued.htm [12 April, 2005].

Morris, A.(1998). 'Our fellow Africans make our lives hell': the lives of Congolese and Nigerians living in Johannesburg. Ethnic and Racial Studies, 21 (6), 1116-1136. 
Mouw, T. \& Xie, Y. (1999). Bilingualism and the academic achievement of first and second generation Asian Americans: Accommodation with or without assimilation? American Sociological Review, 64, 232-252.

Murrell, P. C.(1999). Class and race in negotiating identity.In: A. Garrod, J. Ward, T. Robinson \& R. Kilkenny, (ed). Souls looking back: life stories of growing up Black. USA: Routledge, 3-14.

Neocosmos, M.(2008). The Politics of Fear and the Fear of Politics [online]. Available from: http://www.pa,mbazuka.org/en/category/features/48712 . Accessed 19 July 2011].

Nesdale, D., Rooney, R. \& Smith, L. (1997). Migrant ethnic identity and psycho-logical distress. Journal of Cross Cultural Psychology, 28, 569-588.

Nieto, S. (2002). Language, culture and teaching: critical perspectives for a new century. Mahwah, NJ: Lawrence Erlbaum Associates.

Noguera, P.A. \& Wing, J.Y. (2006). Unfinished Business: Closing the Racial Achievement Gaps in our Schools. San Francisco: Josey Bass.

Osborn, T. A. \& Osborn, D. C. (2005). Introduction: Participating in democracy means participating in schools. In: T.A Osborn (Ed.). Language and cultural diversity in U.S. schools: Democratic principles in action, 1-4. Westport, CT: Praeger.

Panday, S., Makiwane, M., Ranchod \& Letsoalo, T. (2009). Teenage pregnancy in South Africa: With a specific focus on school-going learners. Pretoria, UNICEF.

Patsula, P. J. (1999). Applying learning theories to online instructional design. Athabasca University, Seoul. [Online] http://www.patsula.com/usefo/webbasedlearning/tutoria $11 /$ [9 September, 2005].

Pendleton, W.(2008). Migration and Xenophobia in Southern AfricaIn: H. Hinzen, (ed).Migration and Integration. Number 70 [online] Available from: http://www.iizdvv.de $/$ indez.php?article_id=726\&.clang $=1$ [Accessed 19 July 2011].

Perez, B. (1998). Socio-cultural contexts of language and literacy. Mahwah, NJ: Lawrence Erlbaum.

Pillay, D.(2008). Relative Deprivation, Social Instability and Cultures of Entitlement. In: S. Hassim, T. Kupe \& E. Worby, (Ed.).Go Home or Die Here. Violence, Xenophobia and the Reinvention of Difference in South Africa. Johannesburg: Wits University Press, 93-103.

Qin, D. B., Way, N. \& Mukherjee, P. (2008). The other side of the "model minority" story: The familial and peer challenges 
faced by Chinese American Adolescents. Youth and Society, 39, 480-506.

Reitzes, M.(2009). Xenophobic triggers situated in the history and legal provisions of domestic and international migration policies in South Africa. In: R. Richards, ed. Synopsis, (10)3, 9-14. Policy Studies Bulletin of Centre for Policy Studies.

Reitzes, M.(1994). 'Alien issues'. Indicator SA, 12, 7-11.

Riddle, E. M., and Dabbagh, N. (1999). Lev Vygotsky's Social Development Theory. [Online] http://chd.gse.gmu.edu/immersion/knwledgebase/theori sts/constructivism/vygotsky.htm [18 August, 2005].

Rogoff, B. (2003). The cultural nature of human development. New York: Oxford University Press.

Rumberger, R. W. \& Larson, K. (1998). Toward explaining differences in educational achievement among MexicanAmerican language-minority Students. Sociology of Education, 70, 69-93.

Salinas, C., Franquiz, M.E. \& Reidel, M. (2008). Teaching world geography to late arrival immigrant students: Highlighting practice and content. The Social Studies, 99 (1), 71-76

Sayed, Y. (2002). Exclusion and inclusion in the South with special reference to South Africa. Centre for International Education, University of Sussex. Paper read at CIES "The Social Construction of Marginality: Globalisation's Impact on the Disenfranchised"

Sayed, Y., Soudien, C. \& Carrim, Nazir. (2003). Discourses of Exclusion and Inclusion in the South: Limits and Possibilities. Journal of Educational Change, 4, 231-248.

Scherba de Valenzuela, J. (2002). Socio-cultural Theory. Albuquerque, NM: University of New Mexico. Retrieved Mar. 13, 2009, from

http://www.unm.edu/\%7Edevalenz/handouts/sociocult. html

Schuck, S., \& Kearney, M. (2007). Exploring pedagogy with interactive whiteboards. Sydney: University of Technology. $\begin{array}{llll}\text { Retrieved } & 21 & \text { July2007 from }\end{array}$ www.eddev.uts.edu.au/teachered/research/iwbproject/pd fs /iwbreportweb.pdf

Soto, L. D.(1997). Language, culture and power: Bilingual families and the struggle for quality education. New York: State University of New York Press.

Suarez-Orozco, C. (2004). Formulating identity in a globalized world. In: M.M. Suarez-Orozco \& D.B. Qin-Hilliard, (ed). Globalization, culture and education in the new millennium. London: University of California Press, Ltd. 
Suarez-Orozco, C \& Suarez-Orozco, M.M. (2001). Children of immigration. Cambridge, MA: Harvard University Press.

Taylor, T. \& Doherty, A. (2005). Adolescent sport, recreation and physical education: experiences of recent arrivals to Canada. Sport, Education and Society,10(2), 211-238.

Tharp, R. G. \& Gallimore, R. (1988). Rousing Minds to Life: Teaching, Learning and Schooling in Social Context. Cambridge, England: Cambridge University Press.

Traore, R. \& Lukens, R. (2006). "This isn't the America I thought I'd find": African students in the urban U.S. high school. Lanham, MD: University Press of America.

Traore, R.L. (2004). Colonialism continued: African students in an urban high school in America. Journal of Black Studies, 34(3), 348-369.

Tshitereke, C. (1999). Xenophobia and relative deprivation. Crossings, 3(2), 4-5.

Southern African Migration Project, Idasa, Cape Town and Queen's University, Kingston.

Vandeyar, S. (2008). Shifting Selves: The emergence of new identities in South African schools. International Journal of Educational Development, 28 (3), 286-299. (Nominated for the Joyce Cain award 2009 - Comparative International Education Society).

Vygotsky, L. S. (1978). Mind in society: The development of higher psychological processes. M. Cole, V. John-Steiner, S. Scribner, \& E. Souberman (Eds.). Cambridge, MA: Harvard University Press.

Wang, Y \& Phillion, J. (2007). Chinese American Students Fight for Their Rights. Educational Foundations, Winter-Spring, 91-105.

Wink, J. \&Putney, L. (2002).A Vision of Vygotsky, pp. 102-112 Boston, MA: Allyn Bacon

Winnicott, D. W.(1971).Mirror-role of mother and family in child development. Playing and Reality. London: Penguin.

Wu. F.H.(2002). Yellow: race in America beyond Black and white. New York: Basic books.

Yeh, C. J., Okubo, Y., Ma, P. W., Shea, M., Ou, D. \& Pituc, S. T. (2008). Chinese immigrant high school students' cultural interactions, acculturation, family obligations, language use, and social support. Adolescence, 43, 172, 775-790.

Yeh, G. J. \& Inose, M. (2003). International students' reported English fluency, social Support satisfaction, and social connectedness as predictors of acculturative stress. Counselling Psychology Quarterly, 16, 15-28.

Yeh, G. J. (2003). Age, acculturation, cultural adjustment, and mental health symptoms of Chinese, Korean, and 
Gender \& Behaviour; 9(2), 2011

Japanese immigrant Adolescents. Cultural Diversity and Ethnic Minority Psychology, 9, 34-48. 